\title{
Forest Food and Medicine in Contemporary Appalachia
}

\author{
KATIE TROZZO
}

Virginia Tech

JOHN MUNSELL

Virginia Tech

\section{KIM NIEWOLNY}

Virginia Tech

\section{JAMES L. CHAMBERLAIN}

US Forest Service Southern Research Station

Forest food and medicine have a long history in Appalachian culture, but the region's social landscape is shifting from in-migration of amenity seekers and out-migration of multigenerational residents in search of economic opportunities. As a result, much of what we know about harvest and use has likely changed. We conducted 16 interviews with people involved in harvesting forest food and medicine in a Southwest Virginia community. Our study focused on participants' motivations to work with forest food and medicine, species preferences (edible versus medicinal), and uses (home use versus market sales). Financial benefits, nature, and personal preferences were key motivators. We compared data between multigenerational residents and newcomers to the area. Multigenerational residents emphasized income through market sales of medicinal forest species, noting harvest of multiple product types (plants, bark, leaves, buds). They also mentioned edible species (mushrooms and nuts), but to a lesser degree. On the other hand, newcomers were more likely to balance their focus between medicinal and edible forest species as well as home use and market sales. When compared to multigenerational participants, they were more inclined toward a broad suite of edible species (mushrooms, nuts, fruit, plants); however for medicinal forest species they limited harvesting to herbaceous plants. Shared motivators offer a starting point for regional programs that address the needs of both multigenerational residents and newcomers. As the future unfolds, residents are collectively shaping the next chapter in Appalachia's forest food and medicine culture in a way that meets socioeconomic goals while maintaining the region's natural resources for future generations.

Las comidas y medicinas forestales tienen una larga historia en la cultura apalachina, pero el paisaje social de la región está cambiando de una de inmigración de personas que buscan servicios a una de emigración de residentes multigeneracionales en busca de oportunidades económicas. Como resultado, es muy probable que mucho de lo que sabemos sobre la cosecha y su uso ha cambiado. Realizamos 16 entrevistas con personas que participan en la recolección de alimentos $y$ medicinas forestales en una comunidad del suroeste de Virginia. Nuestro estudio se enfocó 
principalmente en la cosecha de comida forestal y medicina en la comunidad suroeste de Virginia. Nuestro estudió se enfocó en las motivaciones de nuestros participantes trabajar con comida forestal y medicinas, preferencias de especies de plantas (comestible versus medicinal) y usos (ventas de casa versus ventas en el mercado). Beneficios financieros, naturaleza y preferencias personales fueron los motivos principales. Comparamos datos entre residentes multigeneracionales y los recién llegados. Los residentes multigeneracionales destacaron los ingresos que habían ganado a través de las ventas en el mercado de especies de bosques medicinales, señalando la captura de múltiples tipos de estas especies (plantas, corteza, hojas, brotes). También mencionaron especies comestibles (hongos y nueces), pero a menor grado. Por otra parte, los recién llegados tenían más probabilidad de equilibrar su enfoque entre las especies medicinales y comestibles del bosque, así como el uso en sus casas y las ventas en el mercado. En comparación con los participantes multigeneracionales, estaban más inclinados hacia un amplio conjunto de especies comestibles (hongos, nueces, frutas, plantas); sin embargo, para las especies de bosque medicinales, limitaban la cosecha a plantas herbáceas. Los motivadores compartidos ofrecen un punto de partida para los programas de desarrollo que abordan las necesidades de los residentes multigeneracionales y los recién llegados. A medida que se desarrolla el futuro, estos residentes están configurando colectivamente el próximo capítulo en la cultura de alimentos y medicina de los bosques de Appalachia de una manera que responde a las necesidades socioeconómicas al mismo tiempo que mantiene este recurso natural para las futuras generaciones.

KEYWORDS: case study; non-timber forest products; wild harvesting; Virginia; sustainable development
PALABRAS ClAVE: caso de estudio; productos forestales no madereros; cosecha silvestre; Virginia; desarrollo sostenible

HASHTAGS: \# wildfood \# wildmedicine \#foraging \#wildcrafting \#wild harvesting \#Appalachia \#sociallandscape \#non-timber forest products

\section{INTRODUCTION}

Appalachia is broadly defined as the mountainous region of the eastern United States (US) that runs from New York to Georgia and west to Mississippi (Appalachian Regional Commission 2018). It is home to one of the most biologically diverse temperate forest ecosystems in the world (Ricketts et al. 1999), which includes a wide variety of forest food and medicine species (Greene et al. 2000). This natural wealth has supported generations of people that have tended, harvested, and used forest trees, plants, and fungi for food and medicine (Hufford 2003, Cavender 2006; Moerman 2009; Moerman 2010; Freedman 2017).

Non-timber forest products (NTFPs) are products made from plant materials and fungi found in forest ecosystems (Chamberlain et al. 2018). They are referred to by many names, including specialty forest products, and are derived from herbaceous plants, vines, mushrooms, shrubs, and trees. Food and medicine are two major categories of NTFPs; other categories include floral decoratives (e.g., pinecones, fresh/dried flowers, greenery), specialty wood-based products (e.g., walking sticks, stems for furniture, carving wood), and landscaping materials (e.g., transplants, ornamentals) (Chamberlain et al. 2009). Appalachian forests 
are home to over 25 commonly traded medicinal NTFPs and even more that are used for food (Greene et al. 2000).

Forest food and medicine products can support sustainable development by providing livelihood opportunities (Garrity 2004; Ros-Tonen and Wiersum 2005; Griggs et al. 2013) while improving forest health and deepening people's connection with forests. This is a critical issue in Appalachia given that industrialization and globalization have accelerated socioeconomic problems in recent decades (Schumann 2013; Steffen et al. 2015). Extractive industries are no longer engines of economic development (Freudenburg 1992; Floral et al. 2016; Marley 2016) and most of the manufacturing sector has left (Floral et al. 2016). As a result, employment opportunities are limited and poverty levels are high, causing many to leave Appalachia's rural life for work in urban centers (Obermiller and Howe 2013; Pollard and Jacobson 2015). Many of the families that remain in Appalachia are small-scale farmers (Paul et al. 2004; Nehring et al. 2009; Gaventa 2011) who have diversified into alternative production after cash crop tobacco farming was no longer broadly viable (Altman et al. 1996).

At the same time, newcomers are migrating to the region seeking amenity benefits-such as natural beauty, a rural lifestyle, low cost of living, and land for uses like farming - and bring with them different perspectives and values. This shifting social composition could influence the culture of harvesting forest food and medicine in Appalachia. As in other rural areas in the US, Appalachia is at a crossroads and many residents are thinking creatively about how to use local resources-including natural resourcesto support sustainable development and improve livelihoods (Floral et al. 2016). Information about the people, species, motivations, and uses of forest food and medicine in contemporary Appalachia will provide much needed insight into the ways regional programming can improve livelihoods while stewarding the health and sustainability of the region's forests for future generations.

\section{Historical Forest Food and \\ Medicine Context}

Native Americans in the region managed, harvested, and used many species in the forest for food and medicine long before European colonization and much of this culture remains today (Fogelson and Sturtevant 2004; Moerman 2010). The Cherokee people, for example, used nuts from chestnut (Castanea), hickory (Carya), walnut (Juglans), and oak (Quercus) and harvested fruit from wild cherries (Prunus), pawpaw (Asimina triloba), mulberry (Morus), serviceberry (Amelanchier), and persimmon (Diospyros virginiana), among others (Fogelson and Sturtevant 2004). Ramps (Allium triccocum) were also a significant food for many eastern tribes (Moerman 2010). Further, many of the native botanicals that grace the floors of Appalachian forests were important medicinal plants for the Cherokee people, including bloodroot (Sanguinaria canadensis), goldenseal (Hydrastis canadensis), ginseng (Panax quinquefolius), and blue cohosh (Caulophyllum thalictroides) (Moerman 2009). While much of the knowledge about Native American uses of forest plants was lost during European colonization, many Native communities are reviving the cultural practices that survived (Turner and Turner 2008), including through organizations such as the Native American Food 
Sovereignty Alliance (https://nativefood alliance.org/).

European colonization of Appalachia began in the 1700s (Yarnell 1998) and marked a significant change in the region's cultural and natural landscape. Colonizers brought a new worldview of harvesting plants to sell into broader markets (Schelbert 2003). American ginseng (Panax quinquefolius) was a prime example; while sometimes it was used for medicine in the home, it was mostly harvested as a cash crop to supplement farming income (Cavender 2003). Colonizers did, however, rely on other forest species in the home, especially those with analogs in Europe such as ramps (Allium triccocum), wild ginger (Asaram canadense), American chestnut (Castanea dentata), American hazelnuts (Corylus americana and C. cornuta), and black walnut (Juglans nigra) (Wigginton et al. 1975; Cavender 2003; Rivers et al. 2014). Over time, a rich tradition of EuroAmerican folk medicine also developed in Appalachia. Practitioners of this folk craft used both native plants, such as sassafras (Sassafras albidum), slippery elm (Ulmus rubra), and may apple (Podophyllum peltatum), as well as medicinal plants from Europe that became naturalized, such as burdock (Arctium spp) and catnip (Nepta cataria) (Cavender 2003).

\section{Contemporary Forest Food}

and Medicine Context

Forest food and medicine in Appalachia today reflects the region's cultural and natural history, yet the social landscape is shifting. The practice of wild harvesting NTFPs for supplementary income and personal use is still commonplace (Davis and Persons 2014). However, younger generations are increasingly less connected to traditions of harvest and use since they rely less directly on the land (Rigg 2006) and many who hold this knowledge are aging or out-migrating from their communities (Obermiller and Howe 2013; Pollard and Jacobson 2015). At the same time, many newcomers to the region are joining in the harvest of Appalachian forest food and medicine, bringing new perspectives on rural life and stewardship of the natural environment (Chamberlain et al. 2009, Trozzo et al. 2014b), and sometimes living traditions of their own related to foraging and herbalism (Storl 2012; Robbins et al. 2008).

Whether they are new to the area or not, we know very little about what influences contemporary Appalachian residents to harvest forest food and medicine. Although, we do know that age, gender, financial benefits, lifestyle preferences, and concern for the environment affect NTFP harvesting. For example, younger people are often more interested in forest-based specialty crops (Strong and Jacobson 2005; Valdivia and Poulos 2009). Gender has also been observed as a driver, with females making up a significant base of those interested in NTFPs and agricultural systems that include them (Strong and Jacobson 2005; Gao et al. 2014; Trozzo et al. 2014a). Finally, while financial benefits are important, they are often secondary to lifestyle preferences and concern for the environment (Strong and Jacobson 2005; Barbieri and Valdivia 2010). Further, these motivations to harvest forest food and medicine may differ between those who have lived in the region all their lives and those who have recently $\mathrm{mi}$ grated to the area.

Amenity migration is the "movement of people based on the draw of natural and/or cultural amenities" (Gosnell and Abrams 2011, p. 303). Globalization, along 
with cultural and demographic changes, have driven such trends in rural areas across the globe (Cadieux and Hurley 2011, Gosnell and Abrams 2011). The influx of newcomers focused on amenity consumption in rural areas can lead to cultural conflict with multigenerational residents (Hurley and Walker 2004, Walker and Fortmann 2003). In particular, gentrification and development associated with this demographic shift can have measurable impacts on the local landscape and decrease resource access by multigenerational residents who depend on NTFPs for their livelihoods (Cadieux and Hurley 2011; Hurley and Halfacre 2011). On the other hand, benefits are also possible with in-migration of newcomers as they can bring wealth from elsewhere to invest in local initiatives and infrastructure (Gosnell and Abrams 2011). Appalachia is part of this global trend and current amenity migration in the region is changing the social landscape and perhaps influencing forest food and medicine culture (Leebrick 2015). For this reason, the multigenerational and newcomer dichotomy provides a useful framing for our study of forest food and medicine preferences, uses, and motivations in 21st century Appalachia.

Our empirical case study used qualitative methods to investigate the contemporary harvest and use of forest food and medicine in an Appalachian community. Our questions were designed to address three broad themes: Who are the people involved in harvesting forest food and medicine? What motivates them? Which species do they use and how do they use them? To answer these questions, we interviewed residents who were involved in harvesting forest food and medicine in one rural community in Southwest Virginia.

\section{METHODS}

\section{Study area}

For this study, we interviewed community members in Grayson County, Virginia. Grayson County is situated along Virginia's border with North Carolina in the Blue Ridge region of the South Central Appalachia Mountains (Figure 1). Like many Appalachian communities, Grayson County experienced the boom and bust of the timber industry in the first half of the 1900s, followed by the rise and fall of manufacturing in the second half of the century (Maynard and Holton 2013). In 2010, the county had a population of 15,533 , which declined from 17,917 in 2000 due to a combination of death among an aging population and the out-migration of youth (US Census Bureau 2010; Maynard and Holton 2013). Current residents either travel outside the county for work, compete for limited jobs, or face unemployment (Maynard and Holton 2013).

Maynard and Holton (2013) analyzed land cover, economic impacts, and agricultural trends in Grayson County. Farms and forests almost evenly cover most of Grayson's land base. Farming and forestry each bring in over $\$ 2$ million to the local economy. Primary farming crops include dairy and beef cattle, hay, and Christmas trees; secondary crops include tobacco, cabbage, pumpkins, berries, fruit, and vineyards. Local food initiatives have emerged over the last ten years, and include a successful farmers market in Independence, the county seat. Additionally, NTFPs are included as part of the counties strategic plan (Maynard and Holton 2013). Between 2014 and 2017, over 100 local stakeholders participated in a group 

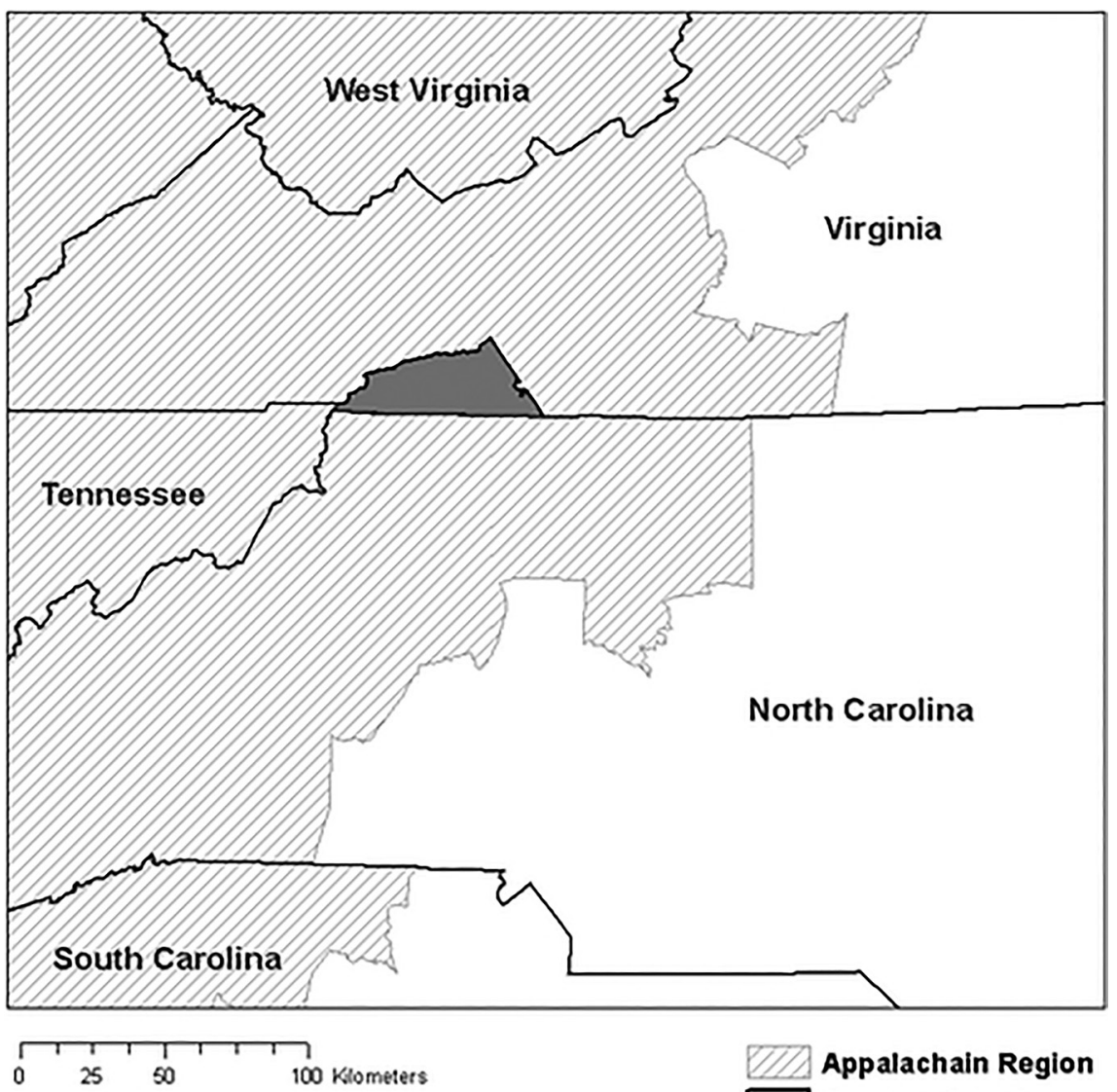

Crested by Katis Trozzo, Apnil 2018

Appalachian Region Boundary from Appalachian Regional Commission 2017

Figure 1. Grayson County is situated along Virginia's border with North Carolina in the Blue Ridge region of the South Central Appalachia Mountains. Case study data were collected through interviews with 16 county residents.

focused on development of these products as part of a community-based component to an associated study (Trozzo, Munsell, Niewolny, and Chamberlain unpublished data).

\section{Interview Protocol}

We conducted 16 semi-structured individual interviews with Grayson County residents between March and October of
2016. Interviewees included people who either directly harvested on public or private land or coordinated harvest on their land by others. We defined forest food and medicine as any plant or mushroom species that grows in the forest and has an edible or medicinal purpose. We selected interviewees from a pool of people who either joined the NTFP interest group formed in January 2014 or were part of a 
referral list created by group participants. We used purposeful selection from this pool to maximize diversity. However, the sample was ultimately influenced by the characteristics of those drawn to involvement in the NTFP group-many of which were predisposed to market sales. Further, variation in gender and resident type was not necessarily representative of Grayson County.

Our interview protocol and questions were approved by the Virginia Tech Institutional Review Board (IRB\# 16-005) prior to conducting the study. The interview protocol provided participants with a brief overview of the project and requested signed consent (Rubin and Rubin 2005). We designed interview questions to understand participant background, experience, motivations, and the species they harvest and use (Table 1). Questions were purposefully open-ended to allow respondents to engage and the interviews lasted between 45 and 90 minutes. Interviews were recorded, and later transcribed and analyzed using qualitative data analysis software (NVIVO 12 QSR International (R) Australia).

Our coding method followed Saldanas (2013), where we used structural coding to organize raw data based on the predetermined line of questioning. Descriptive coding was then used to attribute a first cycle of codes to the structurally adjusted data. We then conducted second cycle analysis involving code mapping and pattern coding to organize codes first into categories and then into central concepts and themes. Additionally, we used matrix coding queries (following Bazeley and Jackson 2013), to conduct comparative pattern analysis between newcomers and multigenerational residents. This helped us describe these groups using their attributes and better understand their differences in codes.

Table 1. Interview topics and questions asked of study participants. Questions were purposefully open-ended and responses were categorized to identify broader themes. References to the themes were then categorized into sub-themes and quantified.

Interview Topics and Questions

Background

When did you arrive in Grayson and what brought you here?

Where were you from before this?

Experience

What is your experience with NTFPs?

Motivations

Why do you work with NTFPs in general?

Species

What NTFPs do you currently grow or steward?

Uses

What do you do with your harvest? 
We tracked categories, sub-categories, and emergent themes based on counts of participants who referenced them and derived percentages from the proportion of total references. We also analyzed attribute data to describe study participants by age, gender, and resident type (newcomer vs. multigenerational resident). We classified a participant as a 'newcomer' if they or their parents moved to the area during or after the 1970s wave of in-migration to rural areas. 'Multigenerational residents' were those whose families were residents of the area before the 1970s and who either lived there all their lives or grew up there and moved back. The 1970s is a common cut off used for distinguishing newcomers and multigenerational residents and consistently provides a clear distinction between the two groups in rural areas of the US (Blahna 1990; Qin 2016). This cutoff was especially fitting for Grayson County because there was a significant demographic shift in the late 1970s into the 1980s prompted by a failed dam project that left more than 14,500 acres of land for purchase (Maynard and Holton 2013).

\section{RESULTS}

Sixteen people participated in this study (Table 2). Eleven self-identified as

Table 2. Demographics and characteristics of all study participants and the breakdown of newcomers and multigenerational residents in a qualitative case study of forest food and medicine perspectives in Grayson County, VA.

\begin{tabular}{llll}
\hline Variable & $\begin{array}{l}\text { All Participants } \\
(\mathrm{n}=16)\end{array}$ & $\begin{array}{l}\text { Newcomers } \\
(\mathrm{n}=10)\end{array}$ & $\begin{array}{l}\text { Multigenerational Residents } \\
(\mathrm{n}=6)\end{array}$ \\
\hline
\end{tabular}

Gender

$\begin{array}{lrrr}\text { Female } & 5 & 5 & 0 \\ \text { Male } & 11 & 5 & 6\end{array}$

Age

$\begin{array}{llll}30-50 \text { years old } & 4 & 3 & 1 \\ 50-70 \text { years old } & 8 & 6 & 2 \\ \text { Over } 70 \text { years old } & 4 & 1 & 3\end{array}$

Experience Level*

$\begin{array}{llll}\text { Lifelong experience } & 4 & 0 & 4 \\ \text { Beginner } & 4 & 4 & 0 \\ \text { Past experience } & 5 & 3 & 4\end{array}$

Invovlement

$\begin{array}{lrrr}\text { Directly harvest } & 14 & 9 & 5 \\ \text { Coordinate harvest } & 2 & 1 & 1\end{array}$

*Experience level emerged as a theme in the data rather than a planned categorical attribute variable collected for all participants, therefore, data is missing for some participants. Also, lifelong experience and past experience are not mutually exclusive, so some participants made reference to both categories. 


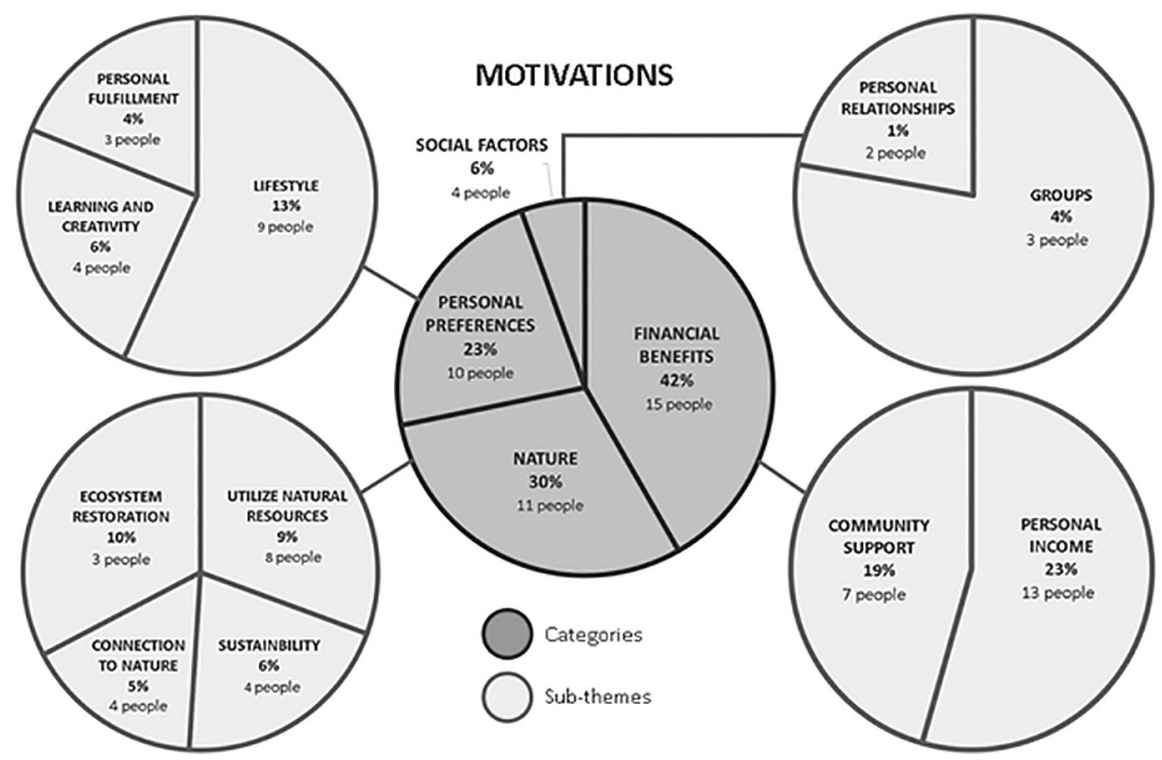

Figure 2. The four main categories of motivations to work with forest food and medicine species along with the percent of the total references to motivations and the number of people who referenced each category (center pie chart). Sub-themes are also shown for each category with their corresponding percent of the total references to motivations and number of people (peripheral pie charts).

male and five self-identified as female. Four participants were between 30 and 50 years old (25 percent), eight were between 50 and 70 years old (50 percent), and four were over 70 years old (25 percent). Ten participants were newcomers to the area and six were multigenerational residents. Half $(n=5)$ of newcomers identified as female and half $(n=5)$ identified as male. All $(n=6)$ multigenerational residents self-identified as male. Multigenerational residents had more participants over the age of 70 and fewer participants under the age of 50. Alternatively, newcomers had more participants between the ages of 50 and 70 . Only multigenerational residents had lifelong experience working with forest food and medicine (since childhood). No newcomers had lifelong experience; instead, four self-identified as beginners or expressed newness to the practice. However, three noted previous experience earlier in their adulthood. Fourteen were directly involved in harvest and two coordinated harvest by others on their land.

\section{Motivations}

Four types of motivations were observed: financial benefits, nature, personal preferences, and social factors (Figure 2). Financial benefits-defined as motivations related to the financial capital used to meet the needs of an individual, family, or community (Flora et al. 2016) -was mentioned most frequently. Sub-themes included personal income-defined as money earned by an individual-and 
community support-defined as financial capital that supports community welfare (Flora et al. 2016). Frequency of mention of the sub-themes were similar, despite fewer people referencing community support. Personal income included references related to farm enterprise diversification or making side income. One participant explained "how do we generate some sort of income off of it? That is kind of what got me going on it." Another noted "it is important that it makes sense as a business and has to be approached and thought out as such." Some saw forest food and medicine as "part of the overall diversity plan for the farm" or one of many "lines of operation." Along the same lines, another said "I am trying to do anything I can to make a little extra money." One clarified that they saw this as being a portion of their income, not "what we do."

Community support focused on supporting community welfare and creating livelihood opportunities by drawing upon forest food and medicine. People pointed to creating a model to share with others, including youth and new growers. Some also discussed how these species have helped raise "operating monies" for local services, such as fire departments. One participant noted that she considered forest food and medicine as a way to "make positive changes in this area as far as improving the socioeconomic conditions" and that she wanted to "create a model that will pay so that other people can use it." Another noted her desire to "find creative ways to earn a living on small acreage." And yet another participant noted that he hoped "to give the young people in this area a reason to stay and raise their families here."

Nature-defined as any motivation relating to the natural environment (Johnson et al. 1997)—was the second most common motivation. We found four subthemes of nature including ecosystem restoration, utilizing natural resources, sustainability, and connection to nature. Ecosystem restoration was defined as motivations related to helping native forest ecosystems recover from degradation and/or damage (Society for Ecological Restoration 2004). Utilizing natural resources included motivations focused on capitalizing on resources available from the forest (Flora et al. 2016). Sustainability included motivations related to harvest of forest food and medicine in a way that maintains species populations and ecosystem function (Tinktin and Shackleton 2011). Connection to nature was defined as motivations related to emotional connections with nature (Perrin and Benassi 2009)

Ecosystem restoration had the highest number of proportional references, but was mentioned by only a small number of people; it included aspects of forest restoration and stewardship. One participant noted the history of her land as being "clear-cut, run for cows, pastured" and then converted into "a white pine plantation." This motivated some in their efforts to restore ecosystem integrity by improving the diversity and health of native plant populations. The same participant really wanted "to see a thriving, diverse forest" and forest food and medicine species were noted as a pathway toward these objectives. "You are enhancing a native plant population and benefiting from it."

Utilizing natural resources had similar proportional references as ecosystem restoration, but was referenced by a greater number of people. References to utilizing natural resources focused on availability 
and use of ample suitable forestland. One participant decided to focus on forest food and medicine by looking at her property "and realizing we have a lot of woodland, why not utilize it?" Another expressed a similar sentiment, "at first I was just wanting to do something with my woods. I have 20 acres here and probably at least half of it is in woods. And I wanted to use it and make it beautiful again and profitable. And just do something really great and different in my woods and use that land."

Sustainability and connection to nature were referenced less frequently than ecosystem restoration and utilizing natural resources. Sustainability included expressions about the draw to work with these species in a way that maintains their populations and uses natural methods. One participant expressed how they wanted to approach production "in a way that doesn't just denude the woods." Another participant noted they would like to be able "to do it in a way that is sustainable" and another emphasized how they focused on natural production methods on their farm with a particular draw to biodynamics and perennial agriculture.

Connection to nature included references to love of nature, the land, the woods, and animals, and appreciation of beauty. One person explained that they want to work with forest food and medicine species "because we love the woods." Another participant discussed how he saw others in his community working with these species because it was "an avenue for them to connect with the land and to be connected to the place they live." Another person described her relationship with the plants and mushrooms she works with "it really does have a spiritual component for me. As does any kind of nature that you personally relate to...it's like if you reach out to it in this way... and really put your heart and your sweat into it... it reaches back and really touches you in such a special way."

Personal preferences were defined as any motivation related to what participants viewed as desirable (Warren et al. 2010) regarding their way of life, their activities, and their approaches to harvesting forest food and medicine. Personal preferences had three subthemes: Lifestyle, learning and creativity, and personal fulfillment. Lifestyle was defined as motivations related to participants' way of life (Sobel 2013). Learning and creativity were defined as motivations related to learning in action and overcoming challenges (Boshyk and Dilworth 2010). Personal fulfillment was defined as a sense of satisfaction and accomplishment (Keller 1987).

Lifestyle was the most significant sub theme and focused on appreciation for the work because of the approachability of the scale, the seasonal work schedule, and slower pace. One participant noted "the scale of it is more for one or two persons," and another described needing a seasonal break "I need that senescence at the end of the year slash the beginning of the year to restart and that is important to me." Beyond the work, others approached it as a way to be outside, a therapeutic activity, and tradition. One participant described it as "something to do for fun."

Learning and creativity, noted less frequently than lifestyle motivations, included references related to curiosity, the enjoyment of learning, creating, innovating, experimenting, and the challenge of working with these species. One participant described "I am just learning so much and learning different things, so it 
just makes you a better person I think... most people would look at this mess and just turn around and walk away, but to me it's a challenge." Another explained how he interacted with forest food and medicine "in terms of curiosity more than anything," and another described how "figuring out ways to make it do better" is one reason he is drawn to forest food and medicine.

Personal fulfillment also followed lifestyle in terms of references and focused on how this activity was a passion, a source of pride, and rewarding for participants. One noted "it's exactly what I want to be doing." Another described it as "just so fulfilling and great. So that is another reason, an important reason for me. It feeds me. It does." Another participant explained "I think most of it has to do with personal pride." He continued "you know the blackberry is ten times better when you have scars to show for it."

The smallest number of references was related to social factors; defined as motivations related to social ties and networks (Gilchrist 2009). Sub-themes included groups-defined as a "collective of individuals who interact and form social relationships" (Abercrombie et al. 2006, p. 174) - and personal relationshipsdefined as interactions of an individual with another (Sweely 1998). The subtheme of groups was more commonly referenced than personal relationships. References to groups were focused on the significance of the NTFP group in the community and how that inspired interest. One participant explained "we had spent a lot of years of exploring on our own and not really knowing how to interconnect." Another noted "it's definitely brought about a different way of thinking about what other opportunities that we may be able to do here on the farm." Another described, "through the woodland growers I have got some inspiration." Personal relationships focused largely on building relationships with others who have shared interests. One participant noted how they enjoyed "talking about it [harvesting forest herbs] to people."

Motivations among newcomers and multigenerational residents differed in several ways (Table 3). Multigenerational residents focused more on financial benefits and most often referenced the associated sub-themes. Newcomers more frequently referenced nature and a greater number of its sub-themes beyond resource utilization. Personal preferences ranked a bit higher for newcomers, though multigenerational residents referenced learning and creativity slightly more often. Multigenerational residents did not mention personal fulfillment at all, although they mentioned social factors slightly more than newcomers. These distinct motivations for harvesting forest food and medicine are not mutually exclusive; many often co-exist to drive participant activity. Newcomers tended to balance motivations of financial benefits, nature, and personal preferences. Multigenerational residents more frequently mentioned financial benefits and they also cited utilizing natural resources (a sub-theme of nature) and lifestyle (a subtheme of personal preferences).

\section{Plant Species Harvested}

Medicinal forest species represented the greatest proportion of overall references and had the largest number of people mentioning them (Figure 3). Medicinal herbaceous plants made up the vast majority of the references to medicinal 
Table 3. The breakdown of newcomer and multigenerational residents' references to each category and sub-theme that emerged around motivations to work with forest food and medicine. The percentages for each category were calculated from the proportion of total references to motivations.

\begin{tabular}{lcc}
\hline & Newcomers $(\mathrm{n}=10)$ & Multigenerational Residents $(\mathrm{n}=6)$ \\
\cline { 2 - 3 } & Total references & Total references \\
\hline Motivations & 114 & 41 \\
& $\%$ references & $\%$ references \\
Financial Benefits & $31 \%$ & $66 \%$ \\
Personal income & $14 \%$ & $46 \%$ \\
Community support & $17 \%$ & $20 \%$ \\
Nature & $38 \%$ & $10 \%$ \\
Utilize natural resources & $9 \%$ & $10 \%$ \\
Sustainability & $9 \%$ & $0 \%$ \\
Connection to nature & $7 \%$ & $0 \%$ \\
Ecosystem restoration & $13 \%$ & $0 \%$ \\
Personal Preferences & $26 \%$ & $17 \%$ \\
Lifestyle & $15 \%$ & $10 \%$ \\
Learning and creativity & $5 \%$ & $7 \%$ \\
Personal fulfillment & $6 \%$ & $7 \%$ \\
Social Factors & $5 \%$ & $5 \%$ \\
Groups & $4 \%$ & $2 \%$ \\
Personal relationships & &
\end{tabular}

species and were noted by the most people. Medicinal plants mentioned most often included ginseng (Panax quinquefolius), goldenseal (Hydrastis canadensis), black cohosh (Actea racemosa), and mayapple (Podophylum peltatum) (Table 4). Medicinal barks were the second most often referenced product and included black cherry (Prunus serotina) and witch hazel (Hamamelis virginiana). A very small percentage of references were made to tree leaves including witch hazel ( $\mathrm{Ha}$ mamelis virginiana) and bigwood leaves (species name unidentified). An even smaller percentage of references were made to tree buds, such as those of tulip poplar (Liriodendron tulipifera) and balm gilead (species name unidentified).

Edible mushrooms were the most commonly referenced edible species, followed closely by nuts. Four people mentioned harvesting wild mushrooms, such as morels (Morchella spp.). Nut tree species included oak (Quercus spp.), black walnut (Juglans nigra), chinkapins (Castanea pumila), and American chestnut (Castanea dentata) for its past significance. Fewer people referenced edible fruit, plants, 


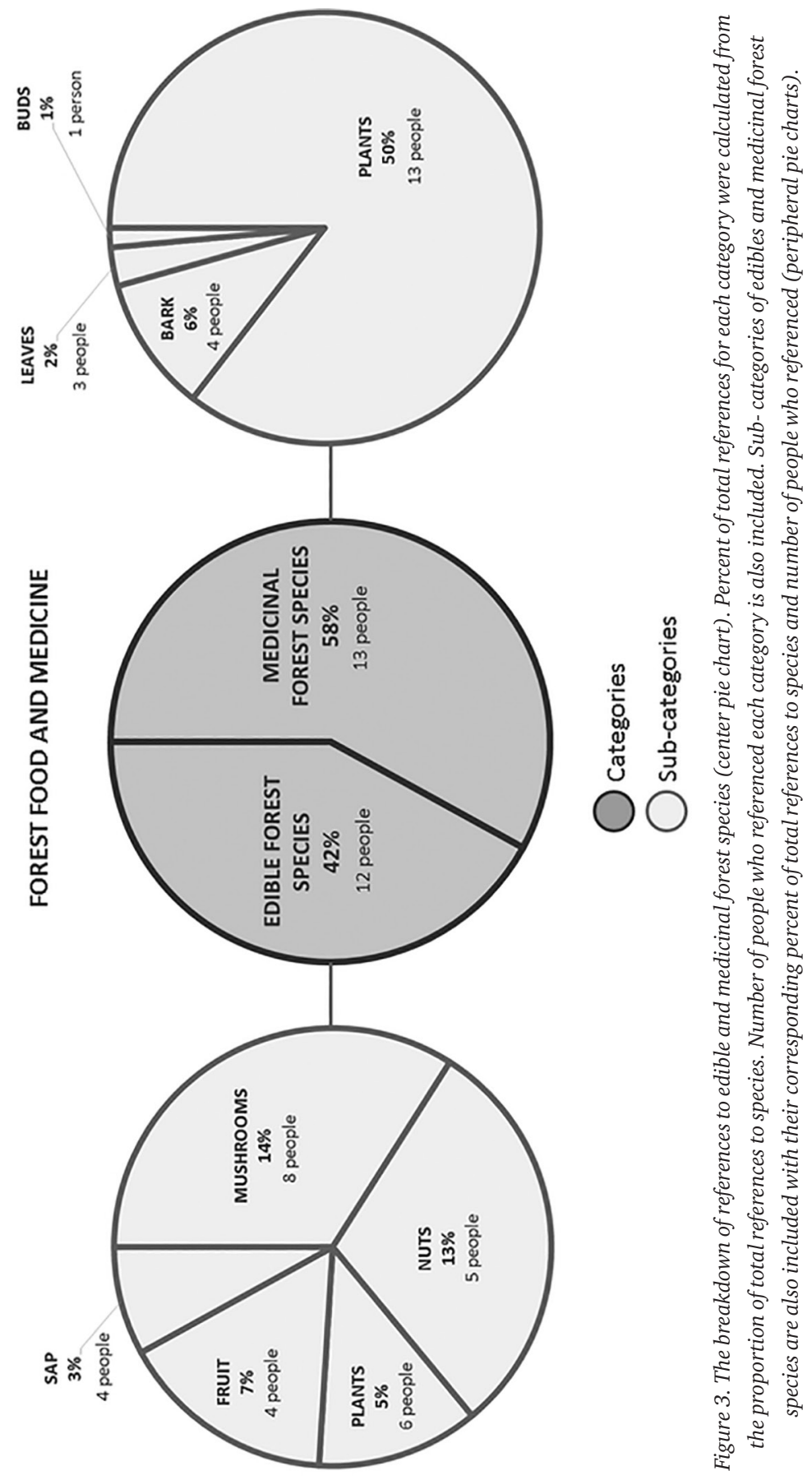


Table 4. The common name, scientific name, number of participants who referenced and frequency of references to medicinal forest species broken down by species type.

\begin{tabular}{|c|c|c|c|}
\hline Common Name & Scientific Name & $\begin{array}{l}\text { Number of } \\
\text { participants who } \\
\text { referenced }\end{array}$ & $\begin{array}{l}\text { Frequency of } \\
\text { references }\end{array}$ \\
\hline
\end{tabular}

Plants

$\begin{array}{llrr}\text { American ginseng } & \text { Panax quinquefolius } & 10 & 11 \\ \text { Goldenseal } & \text { Hydrastis canadensis } & 7 & 14 \\ \text { Black cohosh } & \text { Actea racemosa } & 6 & 11 \\ \text { Mayapple } & \text { Podophylum peltatum } & 5 & 4 \\ \text { Bloodroot } & \text { Sanguinaria canadensis } & 2 & 4 \\ \text { Lobelia } & \text { Lobelia sp. } & 2 & 2 \\ \text { Blue cohosh } & \text { Caulophyllum thalictroides } & 1 & 1 \\ \text { Cranesbill } & \text { Gernanium maculatum } & 1 & 1 \\ \text { Lily of the valley } & \text { Convallaria majuscula } & 1 & 2 \\ \text { Stone root } & \text { Collinsonia canadensis } & 1 & 1 \\ \text { Wild ginger } & \text { Asarum canadense } & 1 & 1 \\ \text { Wild yam } & \text { Dioscorea villosa } & 1 & \end{array}$

Barks

Wild cherry

Witch hazel

Buds

Tulip poplar

Balm gilead

Witch hazel
Prunus serotina

Hamamelis virginiana
11 14

4

4

2

1

1

2

2

1

1

1

1

Liriodendron tulipifera $\quad 1 \quad 1$

Species name unidentified $\quad 1 \quad 1$

Hamamelis virginiana $\quad 1 \quad 1$

Leaves

Witch hazel $\quad$ Hamamelis virginiana $\quad 1 \quad 1$

$\begin{array}{lll}\text { Bigwood leaves } & \text { Species name unidentified } & 2\end{array}$

and tree saps. Fruit species included native fruits such as pawpaw (Asimina triloba), persimmon (Diospyros virginiana), and spicebush (Lindera benzoin) as well as wild apples (Malus spp.). Edible forest plant species included nettles and ramps (Allium triccocum). Sap tree species references were restricted to sugar maple (Acer saccharum).
Newcomers and multigenerational residents differed in their references to these species and plant parts of import (Table 5). Newcomers stated equal preference for medicinal and edible species, focusing on nuts, fruits, and medicinal plants. Multigenerational residents referenced medicinal forest species more frequently than edible species. With regard to forest medicine 
Table 5. The breakdown of newcomer and multigenerational residents' references to forest food and medicine species types. The percentages for each category were calculated from the proportion of total references to forest food and medicine.

\begin{tabular}{lcc}
\hline & Newcomers $(\mathrm{n}=10)$ & Multigenerational Residents $(\mathrm{n}=6)$ \\
\cline { 2 - 3 } & Total references & Total references \\
\hline Forest Food And Medicine & 64 & 59 \\
& $\%$ references & $\%$ references \\
Medicnial Species Types & $47 \%$ & $66 \%$ \\
Plants & $47 \%$ & $51 \%$ \\
Bark & $0 \%$ & $10 \%$ \\
Leaves & $0 \%$ & $3 \%$ \\
Buds & $0 \%$ & $2 \%$ \\
Edible Species Types & $53 \%$ & $34 \%$ \\
Mushrooms & $14 \%$ & $19 \%$ \\
Nuts & $16 \%$ & $7 \%$ \\
Fruit & $14 \%$ & $0 \%$ \\
Plants & $8 \%$ & $3 \%$ \\
Sap & $1 \%$ & $5 \%$ \\
\hline
\end{tabular}

species, only multigenerational residents reported harvesting both herbaceous plants and parts of woody species, such as bark, leaves, and buds. Multigenerational residents also referenced mushrooms and sap more often than newcomers.

\section{Home Use Versus Market Sales}

Two general uses of forest food and medicine were referenced by participants: home use and market sales. Ten people harvested NTFPs for both home use and market sales, two only for home use, and two only for market sales. Newcomers referenced home use and market sales fairly equally, 56 percent and 44 percent respectively. Multigenerational residents dominated in references to market sales (81 percent). Home use included harvesting edible species such as mushrooms, apples, and berries for fresh eating, freezing, or dehydrating. It also included references to preserves and jams. Participants also mentioned making herbal medicine using elderberry, ginseng, and goldenseal. Interestingly, one participant used invasive forest species as fodder for her livestock. One person explained "I am much more homestead minded and that means I want to do a little bit of everything and support us first." Another noted "we just ended up growing for ourselves" and another participant noted something similar "we didn't sell any of it. What we got, it was used."

Market sales included selling both raw harvested products and derived products such as teas, tinctures, and maple syrup. 
Participants discussed selling to intermediate buyers (e.g., local dealers or regional aggregators) or direct to consumers through farm stands, farmers markets, festivals, internet marketing, and store sales. Derived products underwent processing, which may include a combination of cleaning, cutting, or drying; in a few cases, chemical tests were conducted to measure the potency of medicinal roots. One participant expressed the challenge of processing medicinal roots as "the biggest physical thing we had with it was actually cutting the roots to dry. And getting the dirt and all the organics out of the root and getting it prepped to dry." Another noted "it takes a lot of time. I mean a lot of time." Derived products focused on adding value and shelf stability. One participant discussed how "probably the products that are dried are going to be the easiest for me just because the timeline between getting fresh leaves to market. I don't know that I want that stress." Another noted how "a value added product is a great way to get to the market when you are pretty far away from the markets."

\section{DISCUSSION}

This study identified key aspects of the contemporary Appalachian forest food and medicine culture in Grayson County, Virginia and explored motivational differences between newcomers and multigenerational residents. These results must be interpreted with an understanding of our sample since interviewees were drawn from a NTFP interest group-focused on products for sale-and their referrals. Additionally, the interviewees were skewed toward newcomers and males. Despite these limitations, our findings highlight important components of forest food and medicine harvesting in modern-day Appalachia.

\section{Motivations}

Similar to findings of Matthews et al. (1993), personal income was the most frequently mentioned motivator for harvesting. Multigenerational residents tended to focus more on income than newcomers. While this difference could be a product of our sample group, it could also relate to the persistent lack of economic opportunities in the study area. Moreover, newcomers often support themselves using financial capital they accrued elsewhere (Leebrick 2015), bringing to the region a wholly different economic condition. This is likely a key driver in newcomers' tendency to express a wider range of motivations, similar to landowners and farmers interested in specialty forest crops in Pennsylvania (Strong and Jacobson 2005).

Newcomers and multigenerational residents both expressed financial motivations beyond personal income to support community services, initiatives, and the local economy using food and medicine resources available in the forest. Many who referenced community financial support saw forest food and medicine as a way to create livelihood opportunities for the community at large while also protecting the environment. This aspiration was not unlike interest in NTFPs for joint objectives of livelihoods and conservation in other countries (Ros-Tonen and Wiersum 2005).

Factors related to the natural environment also motivated many participants 
and perhaps resemble historical relationships between people and the land in Appalachia (Cavender 2006; Davis and Persons 2014; Freedman 2017). Newcomers and multigenerational residents both noted utilization of natural resources, though newcomers also extended their focus to tending the environment and connecting with nature. This result was similar to Strong and Jacobson's (2005) findings that environmental benefits were important to those interested in specialty forest products. While multigenerational residents may also share concern for nature beyond what can be extracted, they may be less likely to express those perspectives in their actions (Jones et al. 2003). This does not necessarily mean that multigenerational residents are not good stewards of the land (Law and McSweeney 2013). Rather, newcomers may be more vocal about a diversified focus that includes environmental stewardship, sustainability, and connections to nature with financial opportunities.

Similar to findings published by Barbieri and Valdivia (2010) and Strong and Jacobson (2005), lifestyle was a common driver for harvesters of forest food and medicine. Notwithstanding subtle differences, lifestyle preferences were related to the nature of the work and embodied Appalachia's rural character. As Jones et al. (2003) and Leebrick (2015) pointed out, newcomers are attracted to rural Appalachia because of the lifestyle, but our findings also indicated that multigenerational residents appreciated the lifestyle in the region. Interestingly, the presence of learning and creativity as a motivating factor suggested that the complexity associated with forest food and medicine was actually a draw to some. The slightly greater proportion of multigenerational residents who referenced learning and creativity countered the stereotype that often ties these aspirations to newcomers out-migrating from population centers. Personal fulfillment was rarely mentioned by multigenerational participants, which may suggest that these products were so ingrained in their lifestyle and culture that intrinsic motivators became less of a factor. On the other hand, newcomers may have found more personal fulfillment in a practice that was relatively new to them.

While our findings suggest that motivations related to income, nature, and personal preferences played a more substantial role than social factors, it does not necessarily mean that social factors are irrelevant (e.g., Rule et al. 2000; Flora et al. 2016, Bukowski and Munsell 2018). The slightly greater frequency that multigenerational residents mentioned social factors aligned with the tradition of harvesting among family and/or friends or of harvesting individually but being tied to a larger community of practice (Hufford 2003). Further, study participants noted that group interaction and networking around issues of Appalachian forest food and medicine gave them new ideas and spurred interest, which suggested community engagement can provide a springboard for action. Likewise, Trozzo et al. (2014a) found that social influences were an important factor that affected peoples' interest in agroforestry, which includes forest food and medicine species in production systems. 


\section{Plant Species Harvested}

The attention on medicinal forest species among participants was likely influenced by the market focus of many, as well as the extensive role medicinal species play in the Appalachian NTFP industry (Chamberlain et al. 1998). Medicinal species mentioned most often-ginseng (Panax quinquefolius) and goldenseal (Hydrastis canadensis) -were also those with greatest profitability in the market (Burkhart and Jacobson 2009). Multigenerational residents more frequently mentioned them, which may have reflected their general interest in personal income-oriented uses and/or the embeddedness of these species in Appalachian culture, including the tradition of wild harvesting medicinal plants like ginseng for supplementary income (Davis and Persons 2014). Their focus on products beyond herbaceous plants, such as barks, leaves, and buds, perhaps also demonstrates that familial and community traditions instilled in them local ecological knowledge that newcomers do not have (Emery 2001).

Multigenerational residents and newcomers shared a common interest in mushrooms, indicating a convergence of local traditions and newer perspectives. Newcomers focused more on nuts and fruits, possibly due to the popularity of foraging in developed areas (Robbins et al. 2008). Multigenerational residents may not have associated fruits as forest food and medicine since many forest trees only fruit with at least partial sun (e.g., forest edges or gaps). However, edible plants being less prevalent among them was unexpected because of the cultural history associated with species such as ramps (Davis and
Persons 2014; Rivers et al. 2014). There is a chance they may not have mentioned these species because it was so common to them and/or because they responded with market products in mind. Either way, this suggests that newcomers may also be adopting regional cultural traditions around forest food and medicine. Finally, only multigenerational residents referenced maple syrup, perhaps due to their knowledge of potential sugar bushes and historical uses at smaller scales.

\section{Home Use Versus Market Sales}

Market sales and home use were both mentioned as fates for harvested forest food and medicine products. Home use was secondary, however, it is likely more extensive than our findings suggest because of the predisposition of many of the participants toward market sales. Either way, it still received a great deal of attention, which points to 'diverse economies' playing an important role in livelihoods and environmental stewardship despite often being marginalized relative to the market system (Gibson-Graham 2008). While multigenerational residents focused more on market sales than home use, this finding may be skewed due to the lack of women among the multigenerational residents interviewed. Newcomers' balance between market sales and home use suggested a group with mixed interests and perhaps a readied willingness to participate in other economies (e.g., Gibson-Graham 2008). Such non-economic leanings could signal the evolution of a contemporary forest food and medicine practice that includes the provision of edible forest species and a broad, inclusive perspective on foraging. 


\section{CONCLUSION}

Regional history combined with shifts in local demographics have influenced the contemporary state of Appalachia's forest food and medicine culture. The increasing number of people who have moved to the region paired with those that have outmigrated in search of economic opportunity is part of the current social backdrop influencing harvest. Shared motivations between multigenerational residents and newcomers-of personal income, community support, lifestyle and utilizing natural resources-offer a starting point for programs that address the needs of both multigenerational and newcomer harvesters. Opportunities are also ripe for regional programs that promote both market sales and home use. While medicinal species may be a dominant focus in the consciousness of communities, cultural change and a new period of homesteading combined with market sales of a variety of forest foods and medicines is well underway. As they navigate community and regional change, residents are collectively shaping the next legacy of forest food and medicine, one that can be respectful of the past, but responsive to evolving socioeconomic and environmental development goals.

Additional research is needed to understand the nature of forest food and medicine harvests in modern-day Appalachia and ways of supporting this practice to benefit both the people and the land. It will be important to further explore the extent of home uses compared to market sales of forest food and medicine and more closely consider the gendered nature of these two distinct economies. Also important is learning more about sustainable harvesting approaches, such as forest farming, to help improve stewardship of edible and medicinal forest species. Understanding the obstacles Appalachian communities face when developing forest food and medicine opportunities is similarly critical, along with a clear sense of the resources and strategies needed to overcome them.

\section{ACKNOWLEDGEMENTS}

The authors would like to thank the community members in Grayson County, Virginia who made this research possible by sharing their experience. They would also like to thank the Matthews Foundation for their support, and the reviewers and editors who provided feedback on the manuscript.

\section{REFERENCES CITED}

Abercrombie, N., Hill, S., and Turner, B.S. 2006. Dictionary of Sociology. 5 th ed. New York: Penguin Books.

Altman, D.G., Levine, D.W., Howard, D., and Hamilton, H. 1996. Tobacco Farmers and Diversification: Opportunities and Barriers. Tobacco Control 5:192-98.

Appalachian Regional Commission. 2018.

"The Appalachian Region" accessed on July 20, 2018. https://www.arc.gov/ appalachian_region/TheAppalachian Region.asp.

Barbieri, C., and Valdivia, C. 2010. Recreational multifunctionality and its implications for agroforestry diffusion. Agroforestry Systems 79(1):5-18.

Bazeley, P., and Jackson, K. 2013. Qualitative Data Analysis with NVIVO. Washington, D.C.: SAGE.

Blahna, D. 1990. Social bases for conflict in areas of reverse migration. In Community and Forestry: Continuities and Sociology 
of Natural Resources, eds. R.G. Lee, D.R. Field, and W.R. Burch, 159-78. Boulder: Westview Press.

Boshyk, Y., and Dilworth, D.R., eds. 2010. Action Learning. New York City: Palgrave Macmillan.

Bukowski, C.J. and Munsell, J.F. 2018. The Community Food Forest Handbook: How to Plan, Organize, and Nuture Edible Gathering Spaces. White River Junction: Chelsea Green Publishing.

Burkhart, E.P., and Jacobson, M.G. 2009. Transitioning from wild collection to forest cultivation of indigenous medicinal forest plants in Eastern North America is constrained by lack of profitability. Agroforestry Systems 76(2):437-53.

Cadieux, K.V., and Hurley, P.T. 2011. Amenity migration, exurbia, and emerging rural landscapes: Global natural amenity as place and as process. GeoJournal 76(4):297-302.

Cavender, A. 2003. Folk Medicine of Southern Appalachia. Chapel Hill: UNC Press Books. 2006. Folk medical uses of plant foods in Southern Appalachia, United States. Journal of Ethnopharmacology 108(1):74-84.

Chamberlain, J.L., Bush, R., and Hammett, A.L. 1998. Non-timber forest products: The other forest products. Forest Products Journal 48:10-19.

Chamberlain, J.L., Mitchell, D., Brigham, T., Hobby, T., Zabek, L., and Davis, J. 2009. Forest farming practices. In North American Agroforestry: An Integrated Science, ed. H.E. Garrett, 219-55. Madison: American Society of Agronomy.

Chamberlain, J.L., Emery, M.E., and PatelWeynand, T. 2018. Assessment of Nontimber Forest Products in the United States Under Changing Conditions. Asheville: U.S. Department of Agriculture, Forest Service, Southern Research Station. Accessed
October 15, 2018. https://www.srs.fs.usda .gov/pubs/56484

Davis, J. M., and Persons, W.S. 2014. Growing and Marketing Ginseng, Goldenseal and Other Woodland Medicinals. Gabriola Island: New Society.

Emery, M.R. 2001. Who knows? Local non-timber forest product knowledge and stewardship practices in Northern Michigan. Journal of Sustainable Forestry 13(3-4):95-103.

Flora, C.B., Flora, J.L., and Gasteyer, S.P. 2016. Rural Communities: Legacy and Change. 5th ed. Boulder: Westview Press.

Fogelson, R.D., and W.C. Sturtevant, eds. 2004. Handbook of North American Indians, Volume 14: Southeast. Washington, D.C.: Smithsonian Institute.

Freedman, R.L. 2017. Native American food preparation techniques. Boletin Bibliografico de Anthropologica Americana 38(47):101-59.

Freudenburg, W.R. 1992. Addictive economies: Extractive industries and vulnerable localities in a changing world economy. Rural Sociology 57(3):305-32.

Gao, J., Carla, B., Valdivia, C. 2014. A sociodemographic examination of the perceived benefits of agroforestry. Agroforestry Systems 88(2).

Garrity, D.P. 2004. Agroforestry and the achievement of the Millenium Development Goals. Proceedings of the American Mathematical Society 61:5-17.

Gaventa, J. 2011. Communities in Economic Crisis: Appalachia and the South. Ed. J. Gaventa, B.E. Smith, and A. Willingham. Philidelphia: Temple University Press.

Gibson-Graham, J. K. 2008. Diverse economies: Performative practices for 'other worlds.' Progress in Human Geography 32(5):613-32. 
Gilchrist, A. 2009. The Well-connected Community: A Networking Approach to Community Development. Portland: Policy Press.

Greene, S.M., Hammett, A.L., and Kant, S. 2000. Non-timber forest products marketing systems and market players in southwest Virginia: Crafts, medicinal and herbal, and specialty wood products. Journal of Sustainable Forestry 11(3):19-39.

Gosnell, H., and Abrams, J. 2011. Amenity migration: Diverse conceptualizations of drivers, socioeconomic dimensions, and emerging challenges. GeoJournal 76(4):303-22.

Griggs, D., et al. 2013. Sustainable development goals for people and planet. Nature 495(7441): 305-7.

Hufford, M. 2003. Knowing ginseng: The social life of an Appalachian root. In Cahiers de Litterature Orale, 265-91.

Hurley, P.T., and Halfacre, A.C. 2011. Dodging alligators, rattlesnakes, and backyard docks: A political ecology of sweetgrass basket-making and conservation in the South Carolina Lowcountry, USA. GeoJournal 76(4):383-99.

Hurley, P., and Walker, P. 2004. Whose vision? Conspiracy theory and land use planning in Nevada County, California. Environment and Planning A 36(9):1529-1547.

Johnson, D.L. et al. 1997. Meanings of environmental terms. Journal of Environment Quality 26(3):581-89. Jones, R.E., Fly, J.M., Talley, J., and Cordell, H.K. 2003. Green migration into rural America: The new frontier of environmentalism? Society \& Natural Resources 16:221-38.
Keller, J.M. 1987. Strategies for stimulating the motivation to learn. Performance and Instruction 26(8): 1-7.

Law, J., and McSweeney, K. 2013. Looking under the canopy: Rural smallholders and forest recovery in Appalachian Ohio. Geoforum 44:182-92.

Leebrick, R.A. 2015. Rural gentrification and growing regional tourism: New developments in south central Appalachia. In States and Citizens: Accommodations, Facilitation and Resistence to Globalization, edited by J. Shefner. Bingley: Emerald Group Publishing Limited, 215-234.

Marley, B.J. 2016. The coal crisis in Appalachia: Agrarian transformation, commodity frontiers and the geographies of capital. Journal of Agrarian Change 16(2):225-54.

Matthews, S., Pease, S.M, Gordon, A.M., and Williams, P.A. 1993. Landowner perceptions and the adoption of agroforestry practices in southern Ontario, Canada. Agroforestry Systems 21:159-68.

Maynard, M., and Holton, E. Grayson County Comprehensive Plan. Independence: Grayson County Government, 2013.

Moerman, D.E. 2009. Native American Medicinal Plants: An Ethnobotanical Dictionary. Portland: Timber Press. Moerman, D.E. 2010. Native American Food Plants: An Ethnobotanical Dictionary. Portland: Timber Press.

Nehring, R., Gillespie, J., Sandretto, C., and Hallahan, C. 2009. Small U.S. dairy farms: Can they compete? Agricultural Economics 40:817-25.

Obermiller, P.J., and Howe, S.R. 2013. Moving mountains Appalachian migration patterns, 1995-2000. Journal of Appalachian Studies 10(3):359-371. 
Paul, C.M., Nehring, R., Banker, D., and Somwaru, A. 2004. Scale economies and efficiency in U.S. agriculture: Are traditional farms history? Journal of Productivity Analysis 22(3): 185-205.

Perrin, J.L., and Benassi, V.A. 2009. The connectedness to nature scale: A measure of emotional connection to nature? Journal of Environmental Psychology 29(4):434-40.

Pollard, K., and Jacobsen, L.A. The Appalachian region: A data overview from the 2009-2013. American community survey. \#CO-16506-R5-14. Washington, D.C.: Appalachain Regional Commission, 2015

Qin, H. 2016. Newcomers and oldtimers: Do classification methods matter in the study of amenity migration impacts in rural America? Population and Environment 38(1):101-14.

Ricketts, T.H., Dinerstein, E., Olson, D.M, Loucks, C.J., Eichbaum, W., DellaSala, D.A., Kavanagh, K., et al. 1999. Terrestrial Ecoregions of North America: A Conservation Assessment. Washington, D.C.: Island Press.

Rigg, Jonathan. 2006. Land, farming, livelihoods, and poverty: Rethinking the links in the rural south. World Development 34(1):180-202.

Rivers, B., Oliver, R., and Resler, L. 2014. Pungent provisions: The ramp and Appalachian identity. Material Culture 46(1):1-25.

Robbins, P., Emery, M., and Rice, J.L. 2008. Gathering in Thoreau's backyard: Nontimber forest product harvesting as practice. Area 40(2):265-77.

Ros-Tonen, M., and Wiersum, K.F. 2005. The scope for improving rural livelihoods through non-timber forest products: An evolving research agenda. Forests, Trees and Livelihoods 15(2):129-48.

Rubin, H.J., and Rubin, I. 2005. Qualitative Interviewing : The Art of Hearing Data. Thousand Oaks: Sage Publications.

Rule, L.C., Flora, C.B., and Hodge, S.S. 2000. Social Dimensions of Agroforestry. In North American Agroforestry: An Integrated Science and Practice, Madison: American Society of Agronomy, 361-86.

Saldanas, J. 2013. The Coding Manual for Qualitative Researchers. 2nd ed. Washington, D.C.: SAGE Publications.

Schelbert, L. 2003. Pathways of human understanding: An inquiry into Western and North American Indain worldview structures. American Indian Worldview Structures 27(1-2): 61-75.

Schumann, W. 2013. Alternative development and applied anthropology in Appalachia. Practicing Anthropology 35(2):17-22.

Society for Ecological Restoration (SER). 2004. The SER primer on ecological restoration. Society for Ecological Restoration, Science and Policy Working Group. Accessed October 24, 2018. www.ser.org.

Steffen, W., Broadgate, W., Deutsch, L., Gaffney, O., and Ludwig, C. 2015. The trajectory of the Anthropocene: The great acceleration. Anthropocene Review 2(1):81-98.

Sobel, M.E. 2013 Lifestyle and Social Structure: Concepts, Definitions, Analyses. New York: Academic Press.

Storl, W.D. 2012. The Herbal Lore of Wise Women and Wortcunners. Berkeley: North Atlantic Books.

Strong, N.A, and Jacobson, M.G. 2005. Assessing agroforestry adoption potential utilising market segmentation: A case study in Pennsylvania. Small-Scale Forest 
Economics, Management and Policy

4(2):215-28.

Sweely, T.L. 1998. Personal interactions: The implications of spatial arrangement for power relations at Ceren, El Salvador. World Archaeology 29(3):393-406.

Tinktin, T., and Shackleton, C. 2011. Harvesting Nontimber Forest Products Sustainably: Opportunities and Challenges. In Nontimber Forest Products in the Global Context, eds. S. Shackleton, C. Shackleton, and Shanley, P. Hiedelberg: Springer, 254-59.

Trozzo, K.E., Munsell, J.F., and Chamberlain, J.L. 2014a. Landowner interest in multifunctional agroforestry riparian buffers. Agroforestry Systems 88(4):619-29.

Trozzo, K.E., Munsell, J.F., Chamberlain, J.L., and Aust, W.M. 2014b. Potential adoption of agroforestry riparian buffers based on landowner and streamside characteristics. Journal of Soil and Water Conservation 69(2):140-50.

Turner, N.J., and Turner, K.L. 2008. 'Where our women used to get the food:' Cumulative effects and loss of ethnobotanical knowledge and practice. Botany 86(2):103-15.

US Census Bureau (2010). "American Fact Finder." Accessed October 24, 2018. http:// factfinder2.census.gov/faces/nav/jsf/ pages/community_facts.xhtml

Valdivia, C., and Poulos, C. 2009. Factors affecting farm operators' interest in incorporating riparian buffers and forest farming practices in northeast and southeast Missouri. Agroforestry Systems 75(1):61-71.

Walker, P., and Fortmann, L. 2003. Whose landscape? A political ecology of the 'exurban' Sierra. Cultural Geographies 4(10):469-491.
Warren, C. A., Mcgraw, P., and Van Boven, L. 2010. Values and preferences: Defining preference construction. Wiley Interdisciplinary Reviews: Cognitive Science 2(2):193-205.

Wigginton, E., and students, eds. 1975.

Foxfire 3: Animal Care, Banjos and

Dulcimers, Hide Tanning, Summer and Fall Wild Plant Foods, Butter Churns, Ginseng, and Still More Affairs of Plain Living.

New York: Anchor Books.

Yarnell, S.L. 1998. The Southern Appalachains:

A history of the landscape. General

Technical Report (GTR)-SRS-18. Darby, PA:

Diane Publishing.

KATIE TROzzo (ketrozzo@vt.edu) is a PhD Candidate in the Department of Forest Resources and Environmental Conservation at Virginia Tech in Blacksburg, Virginia 24061. Her research interests include agroforestry and sustainable community development opportunities.

DR. JOHN MUNSELL (jfmunsel@vt.edu) is an Associate Professor in the Department of Forest Resources and Environmental Conservation at Virginia Tech in Blacksburg, Virginia 24061. His research interests include private forestland stewardship, agroforestry and whole farm planning, bioenergy and family forest sustainability, collaborative conservation, and integrated natural resources problem solving.

DR. KIM NIEWOLNY (niewolny@vt.edu) is an Associate Professor in the Department of Agricultural, Leadership, and Community Education at Virginia Tech in Blacksburg, Virginia 24061. Her scholarship centers on the role of power and equity in participatory and cultural approaches to community education and development with a focus on 
issues pertaining to community food work, Appalachian food security, new farmer sustainability, and farmworker care/dignity.

DR. JAMES CHAMBERLAIN (jchamberlain@ fs.fed.us) is a Research Forest Products Technologist with the US Forest Service,
Forest Inventory and Analysis in Blacksburg, Virginia 24060. His research focuses on the ecological and economic impacts of harvesting food and medicine from forests, forest farming nontimber forest products, and sustainable management of nontimber forest products. 